\title{
The Influence of Marketing Mix on Student Trust and Its Impact on Competitive Advantage of Private Higher Education Institution
}

\author{
Hendi Sama \\ Student of Universitas 17 Agustus 1945, \\ Surabaya \\ Ida Aju Brahmasari \\ Lecturer of Universitas 17 Agustus 1945 \\ Surabaya \\ Ida Aju Brahma Ratih \\ Lecturer of Universitas 17 Agustus 1945 \\ Surabaya \\ ABSTRACT
}

\begin{abstract}
The purpose of this research is to construct a new concept about the influence of marketing mix to trust and trust towards the competitive advantage of private higher education. The research method of gathering data in this research is by conducting quantitative research. The dissemination of the survey is using simple random sampling at private higher education in Kepulauan Riau (Kepri) province of Indonesia. Respondents from this research are 425 students representing all students of private higher education located in Kepri. The results are Marketing Mix has significant influence to the trust toward private higher education in Kepri province and Trust has a significant effect on the Competitive Advantage of private higher education in Kepri Province. The research concludes that private higher education in Kepri provinces should pay attention to the effect of marketing mix and trust in order to have a suitable competitive advantage.
\end{abstract}

\section{INTRODUCTION}

The university faces the era of the ASEAN free market by the end of 2015, which is the beginning of an era of free market economy, together with the AFTA (North American Free Trade Agreement) and APEC (Asia-Pacific) Economic Cooperation). The impact of all this is inevitably colleges must prepare themselves with various advantages and can benefit from the development situation and conditions in the era of the free market.

Universities must also be able to become a superior institution in order to maintain the continuity of teaching and learning process. Prof. Martinez, and colleagues (Martinez, Smith, \& Humphreys, 2013), describe service to customers to staff, supervisors and administrators in college that they should focus on service to customers because it is closely related to the administrative functions of universities. This is reinforced by Zinaida Fadeeva and Mochizuki (Fadeeva \& Mochizuki, 2010) in Figure 1 which states that in order to be able to maintain the continuity of their vision, a college must pay attention to the service to society, curriculum / teaching, student life, physical operations / infrastructure, research and scholarships, policy and administration planning. 


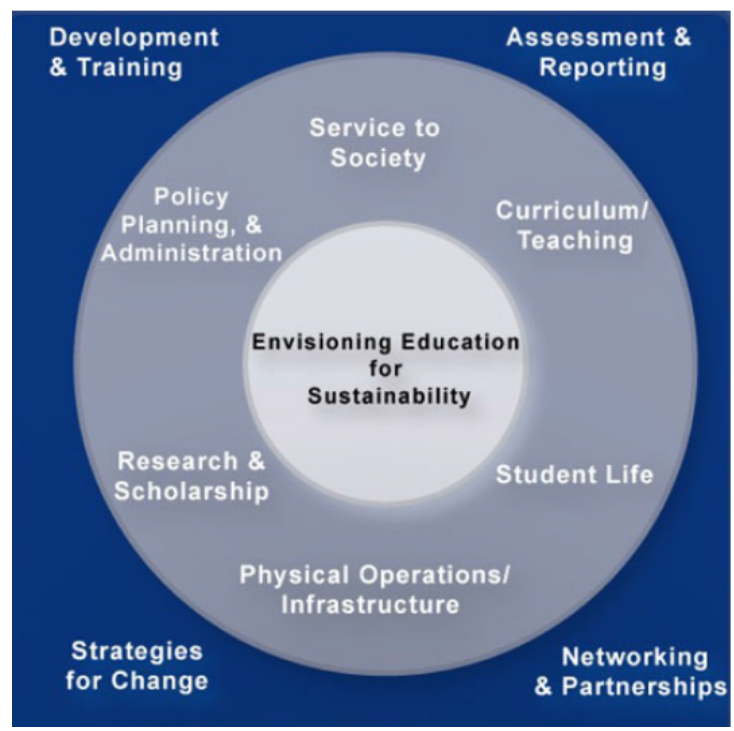

Source: Zinaida Fadeeva, et al. (2010)

Figure 1 Sustainability Project for Resource Cooperation for Universities

The discourse of sustainable development in the world that has always been written in various media has also gained political and social momentum as well as economy, as a reflection of the era of university modernization in the world. There is no doubt that this sustainable development can start from both developed and developing countries.

In developed countries like America and Europe, there is no question of the quality of Harvard University, then Oxford University, which has become the world standard in education. There has been a lot of educational content published by these excellent universities and they have always been a barometer of global education development because of the quality it has guaranteed. Their graduates have proved the result of their work that has spread to various multinational companies in the world.

Universities play an important role in encouraging developments in various fields; The first is the technical field, where the world-class universities have been able to produce engineering planning, manufacturing, processing, and even engineering hardware, software and facilities and infrastructure as well as office automation tools. The second is the field of economics, where reputable college alumni have been able to generate ideas, ideas and analysis in the field of economics, both micro and macro.

Universities can also play an important role in contributing to a more sustainable world by ensuring sustainability through their key educational, research and education functions and community service. Colleges must also know that their sustainability is challenged by external parties, one of them is a more competitive college.

For private higher education in Kepri region itself, based on observations by researchers, from DIKTI (DIKTI, 2016), there arises the phenomenon of decreasing and increasing in the number of students in private higher education in the province of Riau Islands, namely number of students in private higher education of Kepri province in the academic year 2009-1 up by 2015-3.

Based on these results there is a phenomenon that during the years 2009-2015 there was a decrease in the number of students at 4 colleges (19\%), and the increase in the number of students at 17 universities (81\%); It becomes an input to the researcher that whether it is true that it relates to Marketing Mix, and Trust and its impact on University Competitive Advantage. 
From the data and facts the researcher can identify the problem that happened in this research is researching about how the relationship of marketing mix, with trust and competitiveness of college (Study at private university in Kepulauan Riau Province).

Based on the background of problems that have been expressed in the future, then this research problem can be formulated as follows: 1) Is the marketing mix having a significant effect on trust in private higher education in Kepri province? 2) Does trust significantly affect the competitive advantage of private higher education in Kepri province?

\section{Marketing Mix}

\section{CONCEPT}

The marketing mix became popular in the early 1960s, although it was first mentioned in 1949 at the American Marketing Association conference. Based on information from Chaffey and Smith's book (Chaffey \& Smith, 2013), around the early 1960s, a Canadian Jerome McCarthy coined the term ' $4 \mathrm{P}$ ': Product, Price, Place, Promotion. Four P is a controlled variable, which is planned and combined together in the right way, to satisfy the customer. Some controlled factors of the marketing mix include: product quality, product availability, product image, product pricing and services.

In accordance with the opinions of Armstrong and Kotler (Armstrong \& Kotler, 2015), the marketing mix is "a set of marketing tools that work together to meet customer needs and build customer relationships"; and divided into four groups namely product, price, place and promotion, whereas when looking at the holistic marketing, based on the theories of Kotler and Keller (Kotler \& Keller, 2013) that the marketing mix consists of people, processes, programs, and performances. This is according to them marketing mix is seen from the depth, complexity and wealth of a marketing process.

One aspect of the marketing mix is the people who point to the fact that workers and employees or people within the organization are a very critical element for the success of the company's product and service marketing process. This means that people also show that a marketer should view customers as people, to gain a sense of how the customer's lifestyle is broader, and not just as a mere product and service buyer.

Marketing mix reflecting all the creativity, discipline, and structures that are managed in marketing management. A marketer should be able to avoid sudden planning and sudden decisions and must also ensure that the ideas and concepts of the state of the art are executed appropriately. The "program" of the marketing mix reflects the overall activity aimed at consumers, while the "performance" is defined for all activities that generate financial and nonfinancial benefits for the company and also shows its impact on the company in the eyes of the community.

The marketing mix was subsequently developed by Boomer and Bitner in Chaffey and Smith (Chaffey \& Smith, 2013), which added 3 P more into the previous 4 P, which can be shown in the following figure: 


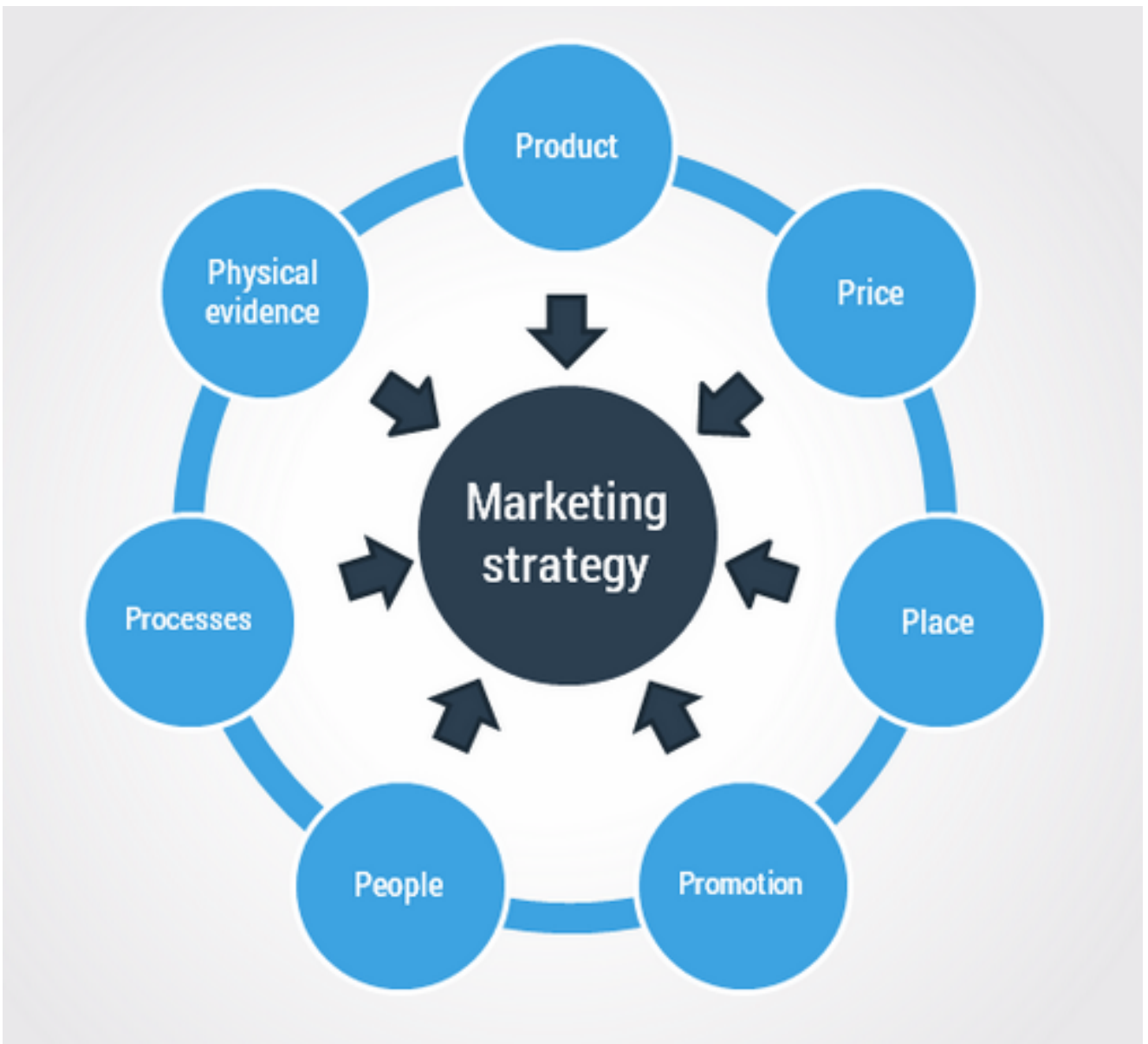

Figure 1. 4P + Processes, People, Physical Evidence Source: Chaffey \& Smith (2013)

Product can be seen from the traditional side, that is product consisting of quality, features and options, style, brand name, packaging, product line, warranty, and service level; while this can also be modified and exploited into quality, brand name, service line, warranty, capabilities, facilitating goods, tangible clues, price, personnel, physical environment, and process of service delivery.

Traditional products, including price, consist of discount and allowances and payment terms, and are modified and expanded into discounted and allowances, payment terms, customer's own perceived value, quality / price interaction, and differentiation; Place, traditionally consists of distribution channels, distribution coverage, outlet locations, sales territories, inventory levels and locations, and transport carriers can also be modified and expanded into locations, accessibility, distribution channels, and distribution coverage; Promotion consists of advertising, personal selling, sales promotion, publicity, and modified and expanded into advertising, personal selling, sales promotion, publicity, personnel, physical environment, facilitating goods, tangible clues, and process of service delivery; Participants can be modified and expanded into Personnel: training discretion, commitment, incentives, appearance, interpersonal behavior, attitudes; Other customers: behavior, degree of involvement, and customer contact; then physical evidence can be modified and expanded into environments: furnishings, colors, layouts, noise levels, facilitating goods, and concrete clues (tangible clues); process can be modified and expanded into policies, procedures, mechanization, employee discretion, customer involvement, customer direction, and flow of activities.

The size of the marketing mix in this study refers to the theories or concept developed by Chaffey and Smith (Chaffey \& Smith, 2013), explaining further on 7P; they assume that the 3P addition - People, the process, and physical evidence - are important in providing services to 
customers. People make and deliver services; but what happens is unhappy customers, and the existing service is in a mess. The process is even more important because the production process, at present, is not on closed doors (as in the case of products) anymore, but is open to all to see how the production process is. In addition, a transparent process has proven itself critical in the successful use of social media.

\section{Trust}

Kotler and Keller (Kotler \& Keller, 2013) states that the trust or credibility of a company is a sphere where customers have the belief that a company can design and produce products and services that can satisfy their needs and wants.

In a study conducted by Charlebois et al. (Charlebois, Palmour, \& Knoppers, 2016), it is defined that Trust is the extent to which one party delivers control to the other in the belief that it will fulfill the duties and responsibilities it respects; This is supported by Elia Ardyan and Vincent Didiek Wiet Aryanto (Ardyan \& Aryanto, 2017) which defines trust in a brand as one's willingness to believe that news, information systems, or something from a third party are reliable, credible, responsible and competent.

Elia Ardyan and Vincent Didiek Wiet Aryanto (Ardyan \& Aryanto, 2017) argued that trust in online brands is the willingness of visitors as readers to trust online news, information systems, or third parties with reliability, credibility, responsibility and competence.

The measure of trust in this study refers to theories or concepts developed by Stephen MR. Covey and Merril (Covey \& Merril, 2013) which includes a) creating transparency; B) better; C) clarification of expectations; D) keep commitments; E) extend trust; F) direct talk; G) show respect; H) true false; I) show loyalty; J) delivers results; K) confront reality; L) practice accountability; M) listen first.

\section{Competitive Advantage}

Porter (Porter, 2008) defines Competitive Advantage as how a company can make the selection and implementation of a common strategy for achieving and maintaining its superiority; In this case there is a link between the types of competitive advantages that are cost and differentiation; with the scope of the company's activities.

Fred R. David (David, 2011) defines competitive advantage as anything a company can do best compared to its competitors. At a time when a company can do something that can not be done by competitors, or have something that is desirable by its competitors, can be said as the competitive advantage of the company.

In research conducted by Helena Stimac and Simic (Stimac \& Simic, 2012), they mentioned that the most dangerous threat to the college market position is competition, especially from colleges that appear to be more flexible and market-oriented. Understanding the value and importance of applying marketing concepts education in the field of higher education is a prerequisite for their successful market performance, due to the dynamic changes in the needs, requirements and values of all stakeholders. David Besanko, et al. (Besanko, Dranove, \& Shanley, 2013) argues that a company's competitive advantage is when a company gets a higher profit economically than the average profit of another company competing in the same market. 
Excellence according to Ramin Jahanbegloo (Jahanbegloo, 2014) , is said as follows: The term "excellence" clearly shows a harmonious vision of the world that sees all cultures and traditions recognizing as a common horizon of global responsibility. Therefore, the idea of excellence is one that all civilizations possess; but the notion of what is best, varies across cultures. Theories about the superiority of universities have been put forward by M. R. Ab Hamid, et al. (Hamid, Mustafa, Suradi, Idris, \& Abdullah, 2012) who said that the performance of universities is measured by 6 indicators: leadership, culture, productivity, employees, shareholders, and overall performance.

In other studies, Ferrell's competitive advantage [22] is something that companies do better than competitors who provide excellence in serving customer needs and / or maintaining mutually satisfying relationships with key shareholders.

Hill and Jones (Hill \& Jones, 2015) argue that competitive advantage is based on a particular advantage, in which a firm has a special power that drives the company to differentiate its product compared to its competitor's product, or offer a cheaper price than its competitors.

Armstrong and Kotler (Armstrong \& Kotler, 2015) define competitive advantage as a greater advantage over competitors earned by offering stronger customer value, either at a cheaper price, or providing more benefits than the price. The measure of competitive advantage in this study refers to theories or concepts developed by Porter (Porter, 2008), which include: 1) Cost Leadership, 2) Differentiation, and 3) Focus.

\section{Relationship between Marketing Mix and Trust}

\section{RELATIONSHIP ANALYSIS}

In accordance with the opinions of Armstrong and Kotler (Armstrong \& Kotler, 2015), the marketing mix is "a set of marketing tools that work together to meet customer needs and build customer relationships"; Divided into four groups: product, price, place (or distribution) and promotion.

Kim, et al. (Kim, Kim, Lee, \& Youn, 2014) says that the marketing mix strategy (with co-brand) has a significant effect on trust. This result is concluded from the results of his research on government employees and customers who make transactions with medium and manufacturing companies in Korea, where the result is trust will increase along with the improvement of product quality and promotion.

Jie Zhang et al. (Zhang, Cohen, \& Larson, 2012), in his research on how to promote honesty in e-market places, concludes that a marketplace operates with buyers' model mechanism, in which buyers follow the advice of other buyers in social media; will earn the trust of the buyer so that in the end get bigger profit.

Ki-Pyeong Kim, et al. (Kim, Kim, Lee, \& Youn, 2014), in his research entitled "The Effects of CoBrand Marketing Mix Strategies On Customer Satisfaction, Trust And Loyalty For Medium And Small Traders And Manufacturers" published in the E \& M Economics and Management Journal Vol.XVII / 1 which discusses relationships between the marketing mix and trust. The aim of the research is to examine whether there is a method for merchants and small producers to reach their competitive level and whether it is possible to co-branding between them, whether there is any effect on the customer and whether customer loyalty can be reinforced by this cobranding strategy. In common with this study is the discussion of the relationship between the marketing mix and trust, while the difference is the research of Kim, using customer satisfaction variables that are not used in this study and the survey conducted on government 
workers and consumers who handle small and medium traders and producers.

Yongrok Choi and Gao (Choi \& Gao, 2014), in his research argued that a direct positive relationship between the components of the web marketing mix and purchasing intentions was partially mediated by initial trust and sustained confidence, while initial beliefs only partially influence purchasing intentions through sustained trust. The similarity with this research is the discussion of the marketing mix, while the difference is in this paper analyzing the core factors of Chinese (relation or Guanxi) trust in improving the marketing mix strategy to determine whether Guanxi can be applied to other web community marketing strategies.

Nina Kurnia Hikmawati et al. (Hikmawati, Sucherly, \& Sumawihardja, 2015) in a study aimed at testing marketing relationships and marketing mixes and influencing customer trust from telecom operators in Indonesia, concluded that the marketing mix has a significant effect on customer trust.

\section{Relationship between Trust and Competitive Advantage}

Singh, S.P., Neha Yadav (Singh \& Yadav, 2014), in his research published in the Journal Research Journal of Management, discusses how the relationship between trust and excellence in universities. The purpose of this study is to investigate the impact of enablers on knowledge management about the competitive advantages of the Indian IT Industry.

Cam Caldwell (Caldwell \& Hansen, 2010), in his research argues that trust can be understood as a source of competitive advantage only when beliefs are understood as behaviors or actions. The equation with this research is that trust is closely related to the company's competitive advantage; The difference is that trust can act as the source of a company's competitive advantage when trust is defined as a customer's behavior or action.

Jollivet (Jollivet, 2011), in his research using the literature, concludes that the mass security associated with trust and cooperation is a tangible social asset that can be judged for the attractiveness of a smart city, its competitive advantage, and its harmonious development. The similarity with this study is that trust is strongly related to the competitive advantage of a mega-city digital; The difference is that trust should be based on evidence and security views of the entire security source en masse.

Julia Connell and Voola (Connel \& Voola, 2013), in a study aimed at examining how and whether industrial cluster members share knowledge through networks as a means of enhancing competitive advantage and, in particular, whether trust is present in the knowledgesharing process; concluded that the survey results reported a positive relationship with respect to trust in the RMO model (relationship marketing orientation), knowledge sharing and competitive advantage. The equation with this research is that research states on the competitive advantages of industry clusters, it has to do with trust when sharing knowledge; The difference is research using relationship marketing orientation (RMO), in 3 time period that is year 2004, 2008 and 2010 .

Singh, S.P., Neha Yadav (Singh \& Yadav, 2014), in his research published in the Journal Research Journal of Management, discusses how the relationship between trust and excellence in universities. The purpose of this study is to investigate the impact of enablers on knowledge management about the competitive advantages of the Indian IT Industry. The similarity with this research is discussion of how the relationship between trust and competitive advantage, while the difference is the existence of enabler variable from knowledge management that is 
collaboration, learning, formalization, centralization, t-shaped skill, behavior, creativity and information technology. In common with this research, there is a positive significant relationship between competitiveness with confidence in the IT industry in India, while the difference is defined trust is the mutual trust between employees who use IT with the IT industry in India.

\section{Relationship Analysis Result}

\section{RESULT ANALYSIS}

The methodology of this research is using casual explanatory research, and from 425 respondents we will analyze how Marketing Mix relate to Trust and Trust relate to Competitive Advantage.

Table 1 Construct Validity Test

\begin{tabular}{|l|l|l|r|c|}
\hline \multicolumn{2}{|c|}{ DESCRIPTION } & ESTIMATION & RELATIONSHIP \\
\hline Trust & $<---$ & Marketing Mix & 0.182 & Weak \\
\hline Competitive Advantage & $<---$ & Trust & 0.554 & Strong \\
\hline
\end{tabular}

Source: Primary Data (2017)

Table 1 shows results from our Structured Equation Model (SEM) analysis. The number 0.182 shows a weak relationship between the Trust construct and the Marketing Mix construct, so it can be said that Trust is not the whole part of the Marketing Mix; while 0,554 indicates a strong relationship between the construct of Competitive Advantage with the construct of Trust, so it can be said that Competitive Advantage is part of the formation of Trust.

\section{Impact Analysis Result}

Table 2 Regression Results

\begin{tabular}{|c|c|c|}
\hline Relationship & & $\mathbf{P}$ \\
\hline Trust & <--- Marketing Mix & 0.000 \\
\hline Competitive Advantage & Trust & 0.000 \\
\hline
\end{tabular}

Source: Primary Data (2017)

Based on the formulation of the problem, the hypothesis analysis presented is as follows: The marketing mix has a significant effect on the trust toward private higher education in Kepri province, based on the result of analysis: $\mathrm{P}$ value on the relationship between Marketing Mix to Trust worth $0.000<0,05$, so it can be concluded that Marketing mix have significant influence to trust toward private higher education in Kepri province. Also based on the formulation of the problem, Trust has a significant effect on the competitive advantage of private higher education in Kepri province, since the result of analysis: P value on the relationship between Trust to the Competitive Advantage is $0.000<0,05$, so it can be concluded that Trust has significant effect to the Competitive Advantage of private higher education in Kepri Province.

\section{CONCLUSION}

The effect of marketing mix variables on trust is significant. The success of private higher education in Kepri province in the utilization of marketing mix in the implementation of academic activities contributed to the increase of confidence of private higher education in Kepri province. The influence of trust variables on the competitive advantage of private higher education in Kepri province is significant. The success of private higher education in Kepri province in fostering and maintaining Institutional Trust can contribute to the increase of competitive advantages of private higher education in Kepri province. In conducting its activities, college should give sufficient attention to the marketing mix both in the product side of the course, marketing products for new students, and services when planning, organizing, 
implementing and evaluating teaching and learning activities in universities. Last point would be communication with all academicians should be maintained by conducting activities or meetings in order to encourage the improvement of trust and especially loyalty of students to the campus.

\section{References}

M. Martinez, B. Smith and K. Humphreys, Creating a service culture in higher education administration, Portland: Ringgold Inc, 2013.

Z. Fadeeva and Y. Mochizuki, "Higher Education for Today and Tomorrow: University Appraisal for Diversity, Innovation and Change Towards Sustainable Development," Integrated Research System for Sustainability Science, pp. 249-256, 2010.

DIKTI, " PDDIKTI," 10:44 AM 3 Mei 2016. [Online]. Available: http://forlap.dikti.go.id/perguruantinggi/homerekap/MUUzMjBFMTEt0Tg1Ri00Qjg3LTk3N0ItQzQ4MkE4NTRC NkQ2/1. [Accessed 10:44 AM 3 Mei 2016].

Chaffey and P. Smith, Emarketing Excellence: Planning and Optimizing Your Digital Marketing, 4th Edition, New York: Routledge, 2013.

G. Armstrong and P. Kotler, Marketing An Introduction, England: Pearson Education Limited, 2015.

P. Kotler and K. L. Keller, Marketing Management, Edinburgh Gate: Pearson Education Limited, 2013.

K. Charlebois, N. Palmour and B. M. Knoppers, "The Adoption of Cloud Computing in the Field of Genomics Research: The Influence of Ethical and Legal Issues," PLOS ONE, pp. 1-33, 2016.

E. Ardyan and V. D. W. Aryanto, "The Importance of Electronics New Brand Trust: The Case of Online Newspapers In Indonesia," in Driving Innovation and Business Success in The Digital Economy, Hershey, IGI Global, 2017, p. 104

S. M. Covey and R. R. Merril, The Speed of Trust, One Thing That Change Everything, Jakarta: Free Press a Division of Simon \& Schuster,Inc., 2013.

M. E. Porter, Competitive Advantage, Tangerang: Karisma Publishing Group, 2008.

F. R. David, Strategic Management Concept and Cases, New Jersey: Prentice Hall, 2011.

H. Stimac and M. L. Simic, "Competitiveness In Higher Education: A Need For Marketing Orientation And Service Quality," Recent Issues in Economic Development, pp. 23-34, 2012.

D. Besanko, D. Dranove and M. Shanley, Economics of Strategy, New York: John Wiley \& Sons, 2013.

R. Jahanbegloo, "The Pursuit of Excellence and the Role of Philosophy," Revista Co-herencia, pp. 179-186, 2014.

M. R. A. Hamid, Z. Mustafa, N. R. M. Suradi, F. Idris and M. Abdullah, "Value-Based Performance Excellence Measurement for Higher Education Institution," Springer Science+Business Media, pp. 3020-3029, 2012.

C. W. L. Hill and G. R. Jones, Strategic Management Theory, Mason: Cengage Learning, 2015.

K.-P. Kim, Y.-O. Kim, M.-K. Lee and M.-K. Youn, "The Effects Of Co-Brand Marketing Mix Strategies On Customer Satisfaction, Trust And Loyalty For Medium And Small Traders And Manufacturers," Journal E\&M Economics and Management, pp. 140-151, 2014.

J. Zhang, R. Cohen and K. Larson, "Combining Trust Modeling And Mechanism Design For Promoting Honesty In EMarketplaces," Computational Intelligence, pp. 549-578, 2012.

Y. Choi and D. Gao, "The Role of Intermediation in the Governance of Sustainable Chinese Web Marketing," Sustainability, pp. 4102-4118, 2014.

N. K. Hikmawati, Sucherly and S. Sumawihardja, "Influence of Marketing Relations and Marketing Mix on Customers Trust On Mobile Service Operators in Indonesia," International Journal of Economics, Commerce and Management, pp. 409-422, 2015.

S. Singh and N. Yadav, "Impact Of Knowledge Management Enablers On Competitive Advantage Of Firms - A Study An Indian IT Industry," Research Journali's Journal of Management, pp. 1-11, 2014.

C. Caldwell and M. H. Hansen, "Trustworthiness, Governance, and Wealth Creation," Journal of Business Ethics, pp. 173-188, 2010. 
P. Jollivet, "Crowd Sourced Security, Trust \& Cooperation for Learning Digital Megacities: Valuing Social Intangible Assets for Competitive Advantage and Harmonious Development," International Communications Satellite Systems Conferences, pp. 261-264, 2011.

J. Connel and R. Voola, "Knowledge Integration and Competitiveness: a Longitudinal Study of an Industry Cluster," Journal of Knowledge Management, pp. 208-225, 2013. 